\title{
Analysis of energy end-use efficiency policy in Spain
}

\author{
Rocio Román \\ University of Seville (Spain) and Universidad Autónoma de Chile (Chile)
}

Teresa Sanz

University of Seville (Spain)

\begin{abstract}
The implementation of saving measures and energy efficiency entails the need to evaluate achievements in terms of energy saving and spending. This paper aims at analysing the effectiveness and economic efficiency of energy saving measures implemented in the Energy Savings and Efficiency Action Plan (2008-2012) (EAP4 +) in Spain for 2010. The lack of assessment related to energy savings achieved and public spending allocated by the EAP4 + justifies the need of this analysis. The results show that the transport and building sectors seem to be the most important, from the energy efficiency perspective. Although they did not reach the direct energy savings that were expected, there is scope for reduction with the appropriate energy measures. For the effectiveness indicator, the best performance are achieved by public service, agricultural and fisheries and building sectors, while in terms of energy efficiency per monetary unit, the best results are achieved by transport, industry and agriculture sectors. Authors conclude that it is necessary that central, regional and local administrations will get involved, in order to get better estimates of the energy savings achieved and thus to affect the design of future energy efficiency measures at the lowest possible cost to the citizens.
\end{abstract}


Key words: Energy end-use efficiency policy, energy intensity, Spain.

\section{Introduction}

Energy efficiency has become one of the basic pillars of EU energy policy in recent decades, with the ultimate goal being to reduce energy consumption, and to contribute positively to the areas of economics, environment and health. To be more specific, these are: in economics, by reducing the energy cost of the sectors and foreign energy dependence; in the environment, by bringing about a reduction of $\mathrm{CO}_{2}$ emissions into the atmosphere and thus mitigating the effects of global warming and climate change; and finally, in health, by reducing emissions of greenhouse gases (GHG) to improve air quality and to decrease the incidence of respiratory and cardiovascular diseases (European Council, 2010).

From the environment point of view, the World Energy Outlook Special Report "Redrawing the Energy-Climate Map" (International Energy Agency,2013), showed the importance of improving energy efficiency policies and investments as the way to halt the increase in emissions by 2020 , without harming economic growth. Recent papers (Hull et al., 2009; Al-Mansour, 2011; Carvalho, 2012; Filippini et al., 2014) have pointed out the importance of the European Energy Efficiency Action Plan, arguing that the current energy efficiency target is not binding and that more effort should be made to achieve the projected $20 \%$ reduction by 2020 . Therefore, this objective was reinforced by Directive 2012/27/EU, where Member States are required to establish minimum energy efficiency targets to meet European objectives on energy consumption. In order to comply with this Directive, Spain has developed the 2014-2020 National Energy Efficiency 
Action Plan. The European Commission (2014) introduced Horizon 2030, that reinforces the importance of low-carbon economies and sets a target of a $40 \%$ reduction in domestic greenhouse gas emissions compared to 1990, due to which, among other objectives, energy savings should be up to $25 \%$.

Although many efforts have been made to summarise the energy savings in the EU-27 through the National Energy Efficiency Action Plans (NEEAP), Linares \& Labandeira (2010) pointed out that the analysis of the effectiveness and efficiency of energy policies should advance and become more widespread. According to this suggestion, some papers have focused on the energy efficiency improvements achieved in some countries, like Lithuania and Slovenia, thanks to the energy efficiency policies and measures implemented (Streimikiene et al., 2012 and Al-Mansour, 2011). Additionally, there are other papers about energy efficiency improvements in specific sectors, such as building. For example, Dineen and Gallachoir (2011) analyse the impacts of measures proposed in Ireland's NEEAP and the Evaluation and Quality Agency (2014) evaluates the energy savigns achieved by the measures implemented in the building sector thanks to the EAP 4+ in Spain. Also, Sobrino and Monzón (2014) analyzes energy efficiency achievements in the transport sector in Spain thanks to energy efficiency plans.

In recent years, Spain has made great efforts to implement energy efficiency policies aimed at eliminating the distance that has historically separated it from the average energy intensity of the European Union. While most European countries have decreased their energy intensity, the Spanish ratio has presented a reverse trend, increasing by $10 \%$ between 1990 and 2006 (Mendiluce et al., 2010). Approval of the 2004-2012 Energy Saving and Efficiency Strategy in November 2003 represented a turning point with regard 
to energy saving policies and the pursuit of standards of existing programmes and measures, something which has been reflected in energy intensity rates ever since. Through the combined efforts of public administrations and manufacturing industries, the energy consumption reduction target set in the 2006 by the Directive 2006/32/EC was achieved by 2010 (Ministry of Industry, Energy and Tourism, 2014).

Mendiluce et al. (2010) and Mendiluce (2012) offer a decomposition analysis of energy consumption changes and energy intensity during two periods, 1995-2006 and 20012010, respectively. In Mendiluce et al. (2010), the authors conclude that the energy intensity ratios in Spain were higher than in the EU15 during the period 1995-2006, with the transport and energy sectors being responsible for two thirds of this difference. In Mendiluce (2012), the decomposition analysis of energy intensity is developed for the period 2001-2010. The author concludes that the trend in energy intensity showed a turning point in 2005 , mainly due to the reduced activity in the construction sector. Additionally, the domestic demand for energy diminished in 2009 due to the Spanish economic crisis. Also, Andrés and Padilla (2015) focus on the analysis of the energy intensity of the road freight transport sector in Spain. These authors conclude that there has been a slight reduction in the energy intensity of this sector in the period 1996-2012.

Additionally, Colinet and Román (2016) focused their analysis of the decomposition of final energy consumption changes in Andalusia (region at the South of Spain) during the period 2003 and 2012. Their results also showed two sub-periods, coinciding to a great extent with the two energy efficiency plans implemented in Andalusia at that period. During the first sub-period, that was 2003-2007, only the residential and energy transformation sectors showed little improvement in energy efficiency. While, during the 
second sub-period, 2008-2012, only the transport and primary sectors improved their energy effiency. With regard to this issue, Sobrino and Monzon (2014) analyze, among other factors, energy consumption associated with the transport sector in Spain in the period 1990-2010, identifying that there was a turning point in 2007 from which energy consumption was reduced due to the economic crisis.

Similarly to Mendiluce (2012), Odyssee (2012) stated that the evolution of the energy efficiency index (ODEX) in Spain recorded a turning point from 2004-2005, when it started to decrease, coinciding with the implementation of the Spanish Energy Saving and Efficiency Strategy (E4, 2003), but also with the effects of the Spanish crisis in the building sector (Mediluce, 2012).

Following Directive 2006/32/EC, Spain adopted its first National Energy Efficiency Action Plan with the Action Plan 2008-2012 (EAP4 +, 2007) in 2007, under the framework of the Spanish Energy Saving and Efficiency Strategy 2004-2012 (E4, 2003). In the case of Spain, the implementation of the EAP 4+ was a follow-up to the previous plan called Action Plan 2004-2007 (AP, 2005). However, the EAP 4+ was considered the first National Energy Efficiency Action Plan because it was the first one put in place after Directive 2006/32/CE.

Later, in 2011, Spain adopted the second National Energy Efficiency Action Plan (EEAP, 2011) in which the results achieved by the EAP $4+$ in 2010 were presented using base years 2004 (first year of reference for the Action Plan 2004 - 2007) and 2007 (reference year of the Action Plan 2008-2012). Furthermore, the results achieved in 2010 (base 2007) served as a reference for the estimates to set goals, in terms of energy savings and 
$\mathrm{CO}_{2}$ emissions, for 2016 and 2020 (Carvalho, 2012). With the aim of contributing to the fight against climate change and GHG emissions, and to reduce both the consumption of fossil fuels and dependence on foreign energy, the measures implemented in the EAP4 + complemented strategies implemented in the Plan for Renewable Energies 2005-2010 (REP, 2005), which committed to a figure of $12.1 \%$ of total energy consumption in 2010 to be supplied by renewable sources. Another measure implemented was the launch of the Spanish Strategy for Climate Change and Clean Energy (EECCEL, 2007) derived from the National Allocation Plan allowances of greenhouse gases 2008-2012 (NAP, 2006).

The aim of this paper is the economic analysis of the energy savings achieved in Spain in 2010 after the implementation of the policy instruments and measures of the first National Energy Efficiency Action Plan during the period 2008-2010. The effectiveness and efficiency of these measures are analysed in a similar manner to that were carried out by Balezentis et al. (2011) and Streimikiene et al. (2012), that is, in terms of energy savings achieved and public funding assigned, compared with the baseline scenario in 2007. An alternative approach was carried out by Haydt et al. (2013). That paper follows Keeney's value-focused, thinking approach (Keeney, 1996) and quantifies the degree of achievement of each objective in five hypothetical energy efficiency plans for Portugal. The objective of this latter paper is to give arguments to policy makers to find the optimal energy efficiency plan in the presence of multiple, and possibly conflicting objectives.

The results of this economic evaluation of the EAP 4+ can help to identify mechanisms and measures that have been demonstrated to be more appropriate for achieving energy 
efficiency targets, and to determine whether measures in the new Spanish Energy Efficiency Action Plan 2011-2020 (EEAP, 2011) are consistent with this assessment.

The paper is structured as follows. After this Introduction, Section 2 explains the methodology used for the analysis. Section 3 presents the explanation of the data sources that have been used for the economic analysis, Section 4 is devoted to the analysis of the results and the discussion divided by sectors (transport, industry, building, equipment, public services and agriculture). Sector 5 explains the uncertainties and limitations regarding the analysis carried out. Section 6 presents the main conclusions.

\section{Methodology.}

The energy savings estimates for 2010 (by EAP4+) and the final data achieved in 2010 reported by the EEAP (2011), both in terms of 2007 (base year), have been used in this paper for the economic analysis. The methodology is based on two economic indicators. First, the effectiveness of energy efficiency measure (i) is calculated as follows:

$$
\text { Effectiveness }_{i}=\frac{\mathrm{es}_{i}^{r}}{\mathrm{es}_{i}^{e}}
$$

where $\mathrm{es}_{i}^{r}$ is the energy saving achieved in 2010 by measure (i) (reported by EEAP, 2011) and es $_{i}^{e}$ is the energy saving estimate for 2010 by measure (i) reported by the EAP4+. The effectiveness indicator in equation (1) gives some information about which are the policy measures that have been proved to be more effective in terms of final energy savings 
achieved in 2010. This indicator allows determination of the percentage achievement of the expected energy savings by measure.

Second, the energy saving by measure (i) per monetary unit is calculated as follows:

$$
\text { Energy saving per euro achieved }{ }_{i}=\frac{\mathrm{es}_{i}^{r}}{p f_{i}^{r}}
$$

where $p f_{i}^{r}$ represents the public funds finally assigned in the implementation of energy saving and efficiency measure (i) in 2010 reported by the EEAP (2011).

The economic indicator in equation (2) gives information about final public expenditure and, therefore, the final energy savings achieved per monetary unit. This last indicator has been calculated not only for energy savings achieved and public funds finally assigned, but also for the energy savings and public funds initially targeted by the EAP4+ (see equation 3).

$$
\text { Energy saving per euro targeted }{ }_{i}=\frac{\mathrm{es}_{i}^{e}}{p f_{i}^{e}}
$$

where $p f_{i}^{e}$ represents the public funds targeted in the implementation of energy saving and efficiency measure (i) in 2010 reported by the EAP4+ (2011).

Of course, wrong estimates could lead to apparently low or high values in effectiveness indicators. For this reason, the European Commission established the roadmap that every Member State must follow in order to avoid this situation (Directive 2006/32/EC). This 
working model includes the top-down and bottom-up indicators that all Member States have to use in order to produce the estimates.

In the case of Spain, the EEAP (2011) confirms that the methodology used to calculate the energy savings achieved in 2010 is the same as that was used in the estimates of the EAP4+. Therefore, they both follow the recommendations on measurement and verification methods within the framework of Directive 2006/32/EC on energy end-use efficiency and energy services.

Therefore, considering the methodology recommended by Directive 2006/32/EC, the total energy savings estimated and displayed in the EAP4+ (2007) include not only the estimation of direct energy savings, but also the indirect energy savings that the implementation of these efficiency measures might provoke additionally to the former. Also, the methodology for the calculations of the estimated energy savings take into consideration the results expected from the implementation of other energy policies that might influence the results, as happens with Directive 2009/28/CE which implies the progressive use of renewable energy in total energy consumption. Overall, the implementation of this methodology to estimate the energy savings involves the combination of top-down and bottom-up methods.

The downward or top-down indicators (which the European Commission separates into $M$ 'minimum' and $P$ 'preferred' indicators) considered, are based on the differences between the year of reference or base year (2004 or 2007) and the year of calculation (2010). These indicators show the energy savings that directly or indirectly result from the application of energy efficiency measures, and also show the energy savings that 
result from technological progress or from other alternative variables, such as the evolution of energy prices and the effects of regulations. Therefore, these indicators employ aggregate information on sector consumption, mode of transport or energy usage plus the statistical data pertaining to the different activity variables. The method for calculating top-down indicators $(\mathrm{P}$ and $\mathrm{M})$ is as follows:

$$
\left(\frac{E_{b y}}{A_{b y}}-\frac{E_{t}}{A_{t}}\right) \times A_{t}=\left(U E_{b y}-U E_{t}\right) \times A_{t}
$$

Where $E_{\text {by }}$ and $E_{t}$ are the energy consumption in the reference year (2004 or 2007) and in the year of calculation (2010) respectively; $A_{b y}$ and $A_{t}$ are the activity variables for the base year and for 2010 respectively. These two variables ( $A_{b y}$ and $A_{t}$ ) are chosen depending on the political measure and the sector where they are applied. The $\mathrm{UE}_{\mathrm{by}}$ and $\mathrm{UE}_{t}$ show the energy consumption by unit of activity in the base year (2004 and 2007) and 2010 respectively. Therefore, the equation 4 shows the energy savings per unit of activity that arise between 2010 and 2004, or 2007. Although the method for calculation the $\mathrm{M}$ and $\mathrm{P}$ indicators appears the same, the difference is based on the activity variables that are chosen. The $\mathrm{M}$ indicators are calculated with more aggregated variables and information, and therefore, the energy savings are attributed to the sector use or mode, while the $\mathrm{P}$ indicators use more specific variables and are therefore are better linked to some efficiency measures.

As a consequence of this, the energy savings calculated by top-down indicators ( $\mathrm{M}$ or $\mathrm{P}$ ) may be due to other reasons different from energy efficiency improvements, especially in the case of $\mathrm{M}$ indicators. For this reason, $\mathrm{M}$ indicators are only calculated when there is 
insufficient good-quality statistical information available (i.e. from the service sector). This is the reason why the main top-down indicators used in the EEAP (2011) are P indicators. The top-down $\mathrm{P}$ indicators have the advantage that, compared with $\mathrm{M}$ indicators, allow economic factors unrelated to energy efficiency or savings to be factored out. Therefore, the effects of the economic crisis were kept to a minimum. The breakdown of top-down indicators by sectors used in the EEAP (2011) are displayed in Table A.1.

The bottom-up indicators show the direct energy savings that can be individually attributed to the energy efficiency measures implemented in each of the sectors and subsectors. The upward or bottom-up calculations are based on reliable information on each energy-saving measure adopted in the course of the period under analysis. The result is calculated by multiplying the difference in energy consumption, before and after adoption, by the number of improvements implemented. They have been calculated in order to estimate the direct savings linked to some implemented energy efficiency measures and, therefore, provide information complementary to top-down indicators. The breakdown of bottom-up indicators used by the EEAP (2011) to calculate direct energy savings by mechanisms and measures is shown in Table A.2.

The methodology for the calculation of bottom-up indicators shows the energy savings achieved due to the efficiency measures implemented by sectors. They are calculated as the difference in energy consumption, before and after the measure implementation, times the number of improvements implemented and times the activity variable percentual change between the base year (2004 or 2007) and the reference year (2010). The calculation method is as follows:

$$
B U_{i}=\sum\left(\mathrm{EC}_{t}-\mathrm{EC}_{b y}\right) \times h \times \frac{\mathrm{A}_{t}}{\mathrm{~A}_{b y}}
$$


Where $B U_{i}$ is the bottom-up indicator for the measure i, $\mathrm{EC}_{t}$ and $\mathrm{EC}_{b y}$ are the energy consumption in the reference year (2010) and in the base year (2004 or 2007) respectively, $h$ is the number of items replaced by the efficiency measure $i$, and $A_{b y}$ and $A_{t}$ are the activity variables chosen for the base year and for the reference year respectively.

As mentioned before, the EEAP uses a combination of top-down and bottom-up indicators in order to calculate the overall energy savings of every sector. Therefore, once the energy savings are calculated with top-down and bottom-up indicators, they are assigned to each sector or measure, in order to calculate real savings without duplicating results. The additions of energy savings calculated through bottom-up indicators in a sector are always lower than the total energy savings assigned to a sector. The reason is that the total energy savings assigned to a sector are calculated with top-down indicators that include not only direct, but also indirect, energy savings. An example of how the results are different for the building sector depending on the indicators used (top-down or bottom-up) are shown in the Evaluation and Quality Agency (2014).

\section{Data}

The analysis of energy savings requires the use of two sources of data for 2010: that provided and estimated by the EAP4+, and that by the EEAP. The first uses estimated energy saving data following the bottom-up methodology, and the EEAP provides energy savings achieved using two methodologies, the bottom-up and the top-down indicators, always following the European Commission methodology. 
Table 1 summarises the information about direct energy savings for 2010 (base year 2007), that is, the energy savings estimated by sector and by measure in the EAP4+ for 2010 (Column 3a), and the energy savings achieved by sector and by measure in 2010 in the EEAP (2011) (Column 3b), both following the bottom-up methodology. When there is lack of data available on the bottom-up indicator, Table 1 displays the symbol N/A (not-available).

In addition to the energy savings data, Column (5), in Table 1, gives information about the public funding assigned to the different measures. This Column is also sub-divided into two Columns (c) and (d) that show the initial amount assigned to each measure and the final public expenditure allocated in 2010 respectively. Public funds, detailed in Table 1, are part of the total investment from the EAP4 + (2007). The remaining investment is private and is expected to be provided by the private agents involved in each sector. The assessment of the EAP4 + (EEAP, 2011) does not include the private investment; only public investment is specified.

The breakdown of energy savings achieved in 2010 (base year 2007) calculated through top-down indicators is shown in Table A.3.

\section{Results and Discussion.}

According to the EAP4+, the energy saving that was expected to be achieved in 2010 , following the bottom-up indicators, was 10,273 ktoe (Table 1, Column 3a). However, the energy saving achieved, calculated with bottom-up indicators, was only 2,642 ktoe (Table 1, Column 3b). There is an important difference between these two amounts that requires further and detailed explanations by sector. Nevertheless, we should bear in mind that 
these lower energy savings are strictly due to the efficiency measures implemented because they are calculated through bottom-up indicators.

Additionally, when the final energy saving achieved was calculated through top-down indicators, it was around 4,720 ktoe (Table A.3), representing 5.3\% of the final energy consumption for the year, which amounted to 88,699 ktoe (EEAP, 2011). In this case, all sectors contributed with positive energy savings except the industry sector due to the decline in production ratios of some industry branches. In this case, the energy savings calculated through top-down indicators show higher energy savings than those shown in Table 1 (Column 3b). The main reason is that in the top-down indicators not only direct energy savings from energy efficiency measures are included. In fact, these indicators are affected by the effects of the economic crisis and by other policies that have been carried out during the same period.

Also, public funding finally allocated in 2010 was approximately 242.6 million euros, which was $48 \%$ less than the budgeted amount (Table 1, Columns 5a and 5b). However, the funds were not reduced proportionally in all sectors as shown in Figure 1. 


\section{Figure 1}

Budgeted versus allocated public funding in 2010

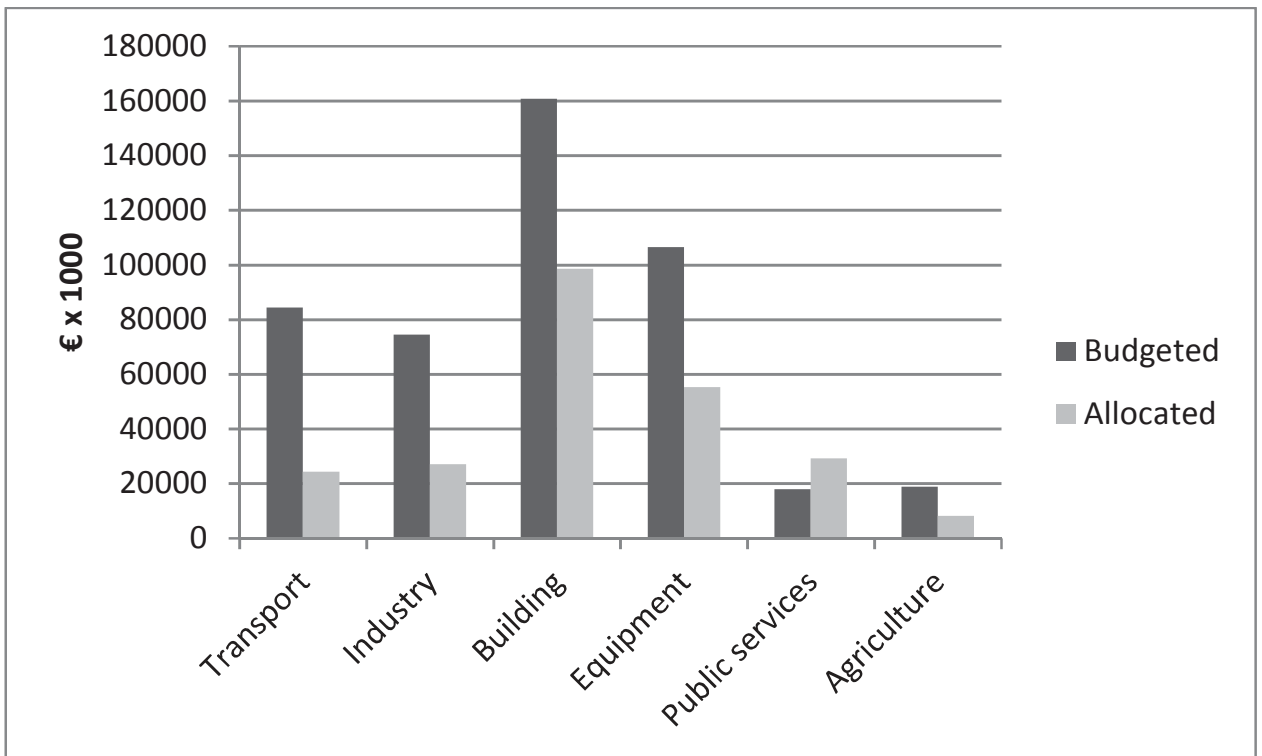

Source: Own elaboration from the EAP4 + (2007) and EEAP (2011).

The analysis of data for public investment by sector shows that, in rank order, the transport and the industry sectors were those that received substantially lower support than was budgeted for. In the case of the transport sector, the reason is mainly due to most of the funds allocated in transport measures having not been registered and, therefore, they are not included in the data provided by the EEAP (2011). Therefore, in the case of the transport sector, the funds allocated cannot be considered to reflect the real situation. In the case of the industry sector, the lower fund allocation is due to most of the budgeted funds having been applied to the measure "grants for strategic projects", but the economic crisis affected this sector more acutely, and the industries did not develop as many strategic projects as expected.

Table 1 
The following subsections are devoted to the analysis and the discussion of the energy savings achieved by sectors and measures in 2010, compared with the estimates, taking into consideration the particular characteristics linked to the methodology of approach that the National Action Plans have used. Additionally, the funds applied by sectors and measures are also discussed.

To sum up, the following highlights of the energy savings by sectors can be considered. All sectors achieved lower direct energy savings after the implementation of efficiency measures than those estimated. The lowest effectiveness indicator is achieved in the transport and equipment sectors (0.2). The energy savings in the transport sector are concentrated in three measures (1,2 and 15) while in the equipment sector they are found in just one (measure 25). This latter received $23 \%$ of public funds although its contribution to the final energy saving was only $3 \%$ in 2010 . The effectiveness of industry measures is 0.5 but in fact, measure 18 is the only one assessed, receiving $11 \%$ of total public funds allocated in 2010. The building sector received the highest percentage of public funds (more than $40 \%$ ) and it attained $21 \%$ of final energy savings in 2010 , being four out of the five measures evaluated (the effectiveness is 0.4 ). The public servicis sector received more public funds than those targeted and the effectiveness of the efficiency measures was the highest (0.7). The effectiveness of measures implemented in the agricultural and fisheries sector was also important (0.6), considering that the public funds finally allocated were $43 \%$ lower than those targeted and $3.3 \%$ of total public funds.

\subsection{Transport sector}

The transport sector was responsible for $36.5 \%$ and $39 \%$ of the total final energy consumed in Spain in 2007 and 2010 respectively (EEAP, 2011), and was a prime target 
for the implementation of energy efficiency policies. For this reason, the transport sector attracted the largest number of energy saving and efficiency measures (15 in total) in the EAP $4+$ and $18 \%$ of planned funds (see Table 1 ).

Although the energy savings estimate for this sector was 6,393 ktoe, Table 1 shows that the energy saving achieved was only 930 ktoe. The reason for this important difference between these two figures might be found in the fact that some energy saving estimates attributed to some transport measures in the EAP4+, measures $6,8,11,13$, and 14 have not been able to be assessed and, therefore, no energy savings have been assigned in the $\operatorname{EEAP}(2011)$.

Data in Table 1 (Column 3b) highlight that measures 1 and 2, related to sustainable urban mobility, have resulted in energy savings of 563 ktoe although was expected to be 1279 ktoe. The basic idea behind these measures is the shift of vehicle type from private car to public transport or to those means of transport consuming no fossil energy.

Besides measures 1 and 2, within the transport sector, the measure 15 is notable for the energy saving achieved (221 ktoe) and is also one of the most important in terms of public funds spent. This measure refers specifically to the various plans that have promoted the purchase of more efficient and less polluting private vehicles. in addition to the environmental benefits and energy savings involved, measure 15 is a very important incentive to the automotive sector in Spain, accounting for 10\% of GDP (if the whole sector is considered) (ANFAC, 2014). Therefore, it has been one of the measures that has had greater continuity over time, with the different editions of the the Spanish Incentive Programme for Efficient Vehicles (PIVE), plans that have encouraged increased car sales. 
In this regard, Mendiluce et al. (2010) argued that this type of measures, such as the promotion of electric vehicles, were necessary to reverse the unsustainable trend in the transport sector.

However, the other measures are far removed from the proposed energy savings objectives. In fact, the energy savings achieved are mostly 1 ktoe and also, the public funding finally allocated are not available for these other sectors. So, the evaluation of these measures through bottom-up indicators is not possible.

Considering the total energy savings achieved by bottom-up indicators in the transport sector (930 ktoe), the effectiveness indicator (Column 4) shows a positive value equal to 0.2. As the estimates for this sector was higher, the effectiveness indicator shows nonfulfilment of the target, despite the positive developments in reducing energy consumption.

Regarding public funds, the transport sector received only $10 \%$ of the public funding through the EAP $4+$ for 2010 (71\% less funds than planned). Nevertheless, data for energy savings per monetary unit demonstrate that the sector achieved higher economic returns than other sectors, demonstrating that improving the efficacy of the implemented measures could have had better results. This is the sector with the best results in Column 6 of Table 1 (38.2 toe/k€), well above other sectors but lower than expected in Column 7 (53.7 toe/k€).

This highlights the importance of reviewing the transport sector measures to identify which are the most effective and to strengthen public investment in such cases. 
Specifically, measures providing the highest economic effectiveness (measures 1, 2 and 15) in the EAP4 + show the highest energy savings achieved per monetary unit, and accounted for $13.5 \%$ of the total public funding provided by the EEAP (2011). In this second plan, measures in the transport sector are the same as those implemented in the EAP4+. Nonetheless, Andrés and Padilla (2015) conclude that further measures to promote alternative means of road freight transport should be encouraged, i.e., promoting measures such as 4 and 5 included in the two plans.

Taking into consideration the energy savings calculated through top-down indicators, the transport sector achieved 4,561 ktoe (see Table A.3). This amount is higher than that shown in Table 1 due to the incorporation of both direct and indirect energy savings.

This figure is completely different from the energy savings estimates including in the EAP4+. For this reason the comparison is not possible. However, the top-down indicators provide complementary information. Analysed by transport mode, road transport is the only one that achieved positive energy savings overall (4,910 ktoe), but freight transport accounted for the bulk of the saving (3,865 ktoe). Sobrino and Monzon (2014) argue that the improvement in energy efficiency in road transport since 2007 has been due to the economic recession in the Spanish economy. The other transport modes achieved negative energy savings and compensate partially, the energy savings of transport sector that shows an increase of energy consumption between 2007 and 2010.

The results coming from the top-down indicators (Table A.3) are influenced by the economic crisis of Spanish economy. In fact, in 2010, there was a decline in freight traffic 
as a result of the reduced industrial production that reversed the rising trend of the period 1990-2008, and this influences factors such as employment, economic activity and income per capita (Mendiluce and Schipper, 2011). Another significant result that shows the effects of the economic crisis is the poor result obtained for the transport of goods by rail; that is, the energy savings were low due to the traffic in 2010 beingonly $72 \%$ of that in 2007. Also, these results are the consequence of the high unemployment rates that many Spanish regions attained due to the economic crisis that reduced urban and interurban movements by transport, especially by car transport (Sobrino and Monzón, 2014).

These results match Spain's ODEX index (Odyssee, 2012), which for 2008-2010 showed an increase in the industrial energy intensity due to the economic crisis, especially in the transport of goods, through its interaction with numerous branches of the economy. Moreover, there was an improvement in private road transport due to technological improvements associated with the progressive penetration of more efficient vehicles into the vehicle fleet, an effect derived largely from the incentives of measure 15 .

\subsection{Industry sector}

In 2010, the industry sector was the second largest sector in terms of final energy consumption (36.2\% of the total) according to the EEAP (2011).

Table 1 displays the energy savings estimated (1,561 ktoe) and achieved (804 ktoe) through bottom-up indicators. In fact, these data are only related to one measure attributed to the industry sector, because the other two are not assessed. The limitation of these data 
led to the conclusion that the effectiveness indicators are not so relevant in this sector, or at least, they are only significant when considering measure 18.

To complement previous data, the energy savings in the industrial sector are displayed in Table A.3 according to the top-down indicators used: a technological indicator and a structural indicator. The technological indicator shows negative energy savings $(-3,988$ ktoe), due to the increase of energy consumption per unit production in some branches of industry. In fact, the chemical industry is the one with the highest negative values.

The structural indicator shows positive energy savings (1,122 ktoe) as a consequence of a change in the structure of the industry sector. In fact, the energy savings occurred as a consequence of the relative weight loss experienced by some industrial sub-sectors linked to the construction sector (Mendiluce, 2012) and the relative weight gain by less energy intensive subsectors.

These results from top-down indicators are consistent with the economic deceleration that the Spanish economy has undergone since 2008. Since then, Spain's ODEX indices have been closely linked to the Spanish ODEX industry index which is the sector that has borne the greatest impact of the Spanish economic crisis (Odyssee, 2012).

The breakdown of energy savings by industrial sub-sectors (Table A.3) confirms that only the branches of Food, beverages and tobacco and Chemicals, show positive savings in the technological indicator (215 and 1,211 ktoe, respectively), while the non-metallic minerals sub-sector shows an important negative value in the technological indicator. 
This is due to the downward trend of the ratio of energy consumption to Gross Value Added in 2009 and 2010.

Regarding the structural indicator, there is a change in the sectoral structure of branches, so that industries with lower energy intensity (wood, cork, furniture, textiles, leather and footwear, electronic equipment and transport equipment, metallurgy, and non-metallic minerals) have a reduced weight in total industry, whereas higher-energy-intensive industries (pulp, paper and paperboard, chemical, food, beverages and tobacco) have an increased weight (EEAP, 2011). Aranda-Usón et al. (2012) suggest the implementation of savings measures in several industries, based on the experience of energy audits. The authors estimate that these measures would provide consumption savings in the Chemical and Food sectors of between $8-19 \%$ and $10-40 \%$, respectively, in thermal energy and in electrical energy of between $9-38 \%$ and $3-40 \%$, respectively. Energy audits is the only measure from the EAP4+ that was included in the EEAP for the industrial sector. This measure is also contained in Directive 2012/27/UE.

\subsection{Building sector}

This sector accounted for $22 \%$ of final energy savings achieved in 2010 , that is, 579 ktoe. This amount is lower than the estimate, which was 1,558 ktoe.

Regarding the building sector, Table 1 shows the five measures included in the EAP4 +, directed at improving the energy efficiency of existing and planned new buildings. Specifically, measures 20 and 21, aimed at improving the energy efficiency of the envelope of private and public buildings, as well as improving the energy efficiency of 
heating systems, air-conditioning and hot water production, have led to a reduction of 18 and 50 ktoe respectively. Although the energy savings achieved with these measures are not very important, they have received the greatest public funding in the sector, with a total of 75.3 million euros in 2010. The Evaluation and Quality Agency (2014) recommended that these measures have to be simultaneously applied in order to improve the energy savings outcomes.

Additionally, measures 22 (directed at improving the energy efficiency of interior lighting) and 23 (promotion of construction of new buildings and rehabilitation of existing buildings with high energy rating) are also relevant from the point of view of the energy savings achieved, 301 and 228 ktoe respectively, with a relatively low budget, showing energy savings per monetary unit of around 14 and 112 toe/k€ respectively.

Measure 24 (Revision of energy requirements in building regulations), which has not been estimated nor assessed, is the only one that seems to follow a holistic approach as Annunziata et al. (2014) suggest, when they affirm that in the building sector, the low budget and short payback time, are characteristics that tend to prevail over the logic of an optimal planning for resource efficiency. As a consequence, stand-alone initiatives often prevail over more systemic investments that gradually become an overall objective.

The Building sector received the highest percentage of public investment in 2010 (41\%), being responsible for $21 \%$ of final energy consumption in that year. However, the energy saving per monetary unit was 5.9 toe/ $\mathrm{k} €$, demonstrating a low return despite its importance in terms of final energy consumption. These data support the need to promote those measures that are more efficient in order to be included in the EEAP (2011). In fact, 
the building sector accounts for 67\% of total public funding allocated in the EEAP (2011). This budget is displyed in six measures, being fourth of them included in the first plan (measures 20 to 23) and two new ones are included, one is oriented to improving the energy efficiency of cold commercial plants and the other promotes the construction or renewal of buildings with nearly zero energy consumption.

When considering the energy savings achieved, calculated through top-down indicators in the building sector (Table A.3), they become very important, around 2,322 ktoe. Again, it should be taken into account that this data includes not only the direct, but also the indirect energy savings achieved through the efficiency measures. In fact, the highest energy savings were attributed to the rehabilitation and improvement of buildings and installations that were also considered by the bottom-up indicators.

Therefore, the energy savings achieved by this sector when direct and indirect measures are considered (with top-down indicators) are largely influenced by the impetus provided by legislation for this purpose, namely the Technical Building Code (RD 314/2006), Regulation of Thermal Installation in Buildings (RD 1027/2007) and the mandatory energy certification of buildings (RD 47/2007). A review of the measures implemented under the programme "Low Resource consumption in buildings and construction by use of Life Cicle Assessment in design and decision-making (LoRe-LCA) between 2007 and 2012, shows that the materials used for construction and renovation are among the elements that better contribute to energy efficiency gains in the building sector (Zabalza et al., 2011). Also, Fernández-Membrive et al. (2015) argue that the new legislations in the building sector facilitated the improvement of energy efficiency, although they consider that there is still room for potential energy savings in the case of homes built 
before 2006. However, Mendiluce et al. (2010) state that the coincidence of this new legislation with the beginning of the decline in the construction sector reduced the effectiveness of this legislation due to the building stock remaining unchanged.

Additionally, this result agrees with Spain's ODEX index which converges with the European average for the residential sector in 2010, after having a downward trend for several years (Odyssee, 2012). Despite the good results achieved in the building sector through top-down indicators, as Tolon-Becerra et al. (2013) point out, further energy efficiency improvements in the Spanish building sector will be difficult in the short-term, in the Spanish economy, because of, among others factors, the lack of motivation of citizens in the field of energy saving and the economic crisis, which has slowed the sale of new houses and resales, reducing housing rehabilitation and new construction, due to the large current stock of housing for sale.

\subsection{Equipment sector}

The equipment sector includes the energy consumption of household appliances, air conditioners of less than $12 \mathrm{~kW}$ and office equipment in the domestic and other sectors.

The energy savings achieved by bottom-up indicators are 56 ktoe (see Table 1), lower than was estimated (346 ktoe). The most important measure implemented in the

equipment sector is measure 25 (Renewal Plan), aimed at replacing low energy rating appliances, i.e., inefficient appliances, with higher-efficiency appliances whose energy labelling is an "A" or higher. This measure absorbed the largest share of targeted public funding in absolute terms in the EAP4 + for 2010, but the final energy saving achieved 
with this measure was only 56 ktoe. As Galarraga et al. (2013) indicated, the application of measures, such as the Spanish Renewal plan, generated some welfare losses, a rebound effect and a considerable deficit in public budgets. In that paper the authors compared some alternatives such as taxes and rebates in the case of dishwashers for a Spanish region, however they have not evaluated the results from the EEAP (2011).

The equipment sector produced a poor result regarding effectiveness (0.2). One reason that explains this result is that since its launch in 2006, the Appliance Renewal Plan has allowed for over 3 million replacements of conventional appliances by others with superior energy ratings; however there has been an increase in the energy consumption of households and the service sector, due to an increase in the number of appliances (Mendiluce et al., 2010). As Galarraga et al. (2016) indicated, it would be more profitable for the government to use a combination of discounts and taxes, instead of using the discounting mechanism as part of the purchase price as established by this measure.

The equipment sector accounted for 5\% of the final energy consumption in 2010 and received $23 \%$ of the public funding for that year. However, the measures implemented in this sector have not achieved the intended objectives, and the energy saving achieved per monetary unit was only 1 toe/k€, far removed from the estimated 325 toe/k€.

Thus, it seems appropriate to analyse how to achieve higher efficacy and costeffectiveness in this sector, given that its contribution to final energy saving in 2010 was only 3\%. However, in the second Action Plan, the EEAP (2011), almost all public investment for this sector was destined to promote measures similar to those in the former Plan, accounting for $10 \%$ of total public funding in the new plan. 
On the other hand, the energy savings achieved by this sector calculated through topdown indicators was around 207 ktoe (see Table A.3). These energy savings are explained mainly by the reduction in the unitary consumption of appliances, although they are calculated with $\mathrm{P}$ and $\mathrm{M}$ indicators. As we mentioned before, the $\mathrm{M}$ indicators include further effects than those attributed to the efficiency measures implemented in this sector.

The results of this analysis show that the measures implemented in this sector does not seem to achieve high energy savings but they have not been revised by the EEAP (2011). On the contrary, they all have been included.

\subsection{Public Services sector}

The public services sector only accounted for approximately $0.6 \%$ of the national energy consumption in 2007, while in 2010 it was $1 \%$, excluding the energy consumption for non-energy uses (EEAP, 2011).

The energy savings estimate through bottom-up indicators was 138 ktoe, close to the energy saving finally achieved which was 102 ktoe (see Table 1).

Considering these data, the highest value of the effectiveness indicator was obtained by the public services sector (0.7). The most important measures in the public service sector from the energy savings achieved perspective are 27 and 28 (Table 1). They were both expected to achieve $92 \mathrm{ktoe}$, but finally achieved $98 \mathrm{ktoe}$. In fact, although the energy 
savings are assigned to both efficiency measures, only the first was previously estimated in the EAP4+.

In the EAP4+, no potential energy savings were assigned to measures 28 and 29 . This explains why no achieved energy savings have been calculated, as the EEAP considers that they are unquantified effects.

Measure 30 is devoted to the improvement of the water supply. The energy savings achieved are insignificant (4 ktoe), although the top-down indicators show that they achieved 17 ktoe (see Table A.3). The reason is that there are indirect effects, meaning that the actual savings could not be quantified precisely.

The public services sector accounted for around 4\% of energy savings achieved in 2010 but received a higher percentage of public funds than was estimated $(12 \%)$. Therefore, the energy saving achieved per monetary unit was 3.5 toe/€, just half of than that estimated (7.7 toe/€).

When the top-down calculations are considered, this sector has not achieved important energy savings, as Table A.3 shows (29 ktoe). In fact, this is the only sector where the direct energy savings are higher than the total energy savings calculated with top-down indicators. This negative difference arises from the existence of a rebound effect.

Particularly, with regard to street lighting, the difference between the top-down calculations (consumption of street lighting per house) in Table A.3 and the bottom-up energy savings calculations (measure 27 and 28) in Table 1 is also negative (-87 ktoe). 
This result means that the direct energy savings resulting from efficiency measures are offset by other effects. First, the improvement in efficiency resulting in reduced levels of consumption might be offset by an extension of the hours of operation. Second, urban development has played an important role in achieving the savings because the street lighting installations are proportional to the number of new buildings, thus, up to 2008 , the urban development in Spain considerably increased the consumption of street lighting.

\subsection{Agricultural and Fisheries Sector}

The agriculture and fisheries sector had a contributory weight in the final energy consumption in Spain of 3.5\% in 2007 (EEAP, 2011). The main sources of energy consumption in this sector are agricultural machinery, irrigation systems and fisheries.

Table 1 shows the seven measures implemented in this sector. The energy savings estimate was 277 ktoe, while that achieved was 171 ktoe. The best results were achieved by measures 32 and 33 (120 ktoe) aiming at improving the efficiency of tractors. On the other hand, only measure 36, which is aimed at improving effectiveness in the fisheries sub-sector, achieved savings of $18.5 \mathrm{ktoe}$, representing an $11 \%$ contribution to the total energy savings achieved by the sector (EAP 4+, 2007).

The results for agriculture and fisheries are significant because, with only $2 \%$ of public funding spent through the EAP 4+ in 2010, the sector achieved an effectiveness indicator value of 0.6. This might be explained firstly, due to a decline in production, and secondly, to the technological improvements that resulted in energy savings in the use of agricultural machinery and irrigation systems. Additionally, this sector shows an economy indicator value of 21 toe/k€. These results demonstrate the high effectiveness 
of the measures proposed for the sector. However, the amount of energy saving in agriculture and fisheries could have been even greater if the installation of air conditioning in farming and greenhouses had achieved better results. In the second plan, the proposed measures are similar, although there is a greater presence of the fisheries sector.

Although this sector's contribution to final energy savings in 2010 was only $6 \%$, the results show that the funds allocated have a relatively high importance and therefore the energy savings achieved per monetary unit have exceeded the targeted results (15 toe/k€).

When the energy savings achieved calculated through top-down indicators are considered (Table A.3), the figures are higher, around 467 ktoe. Despite the good results of this sector, its impact on improving Spanish energy intensity is very moderate, due to the reduced weight in the Spanish economy (Fernández et al., 2013).

\section{Limitations and uncertainties about energy savings achieved in 2010.}

The economic analysis of the targeted energy savings and those actually achieved through the implementation of efficiency measures, requires further explanation because some limitations and uncertainties arise.

Firstly, apparently, energy saving estimates and calculations are based on the same approach, that is, a top-down and bottom-up combination. The targeted energy savings have been established by a bottom-up analysis in the EAP4+, considering all energy 
consuming sectors and, in addition, a comprehensive analysis of the macroeconomic scenarios has been undertaken in order to identify the general paths of energy consumption. The EEAP quantifies the savings achieved using the method recommended by the European Commission in the document, "Recommendations on Measurement and Verification Methods in the Framework of Directive 2006/32/EC on Energy End-Use Efficiency and Energy Services". This method was the result of a combination of "topdown' indicators and 'bottom-up' calculations.

However, while the EEAP clearly identifies the energy savings calculations that come from either top-down or bottom-up indicators, the EAP4+ presents the energy savings estimates less accurately than the EEAP, and it is difficult to know the origin of the energy savings estimates, that is, whether they come from bottom-up or top-down indicators. For that reason, the existence of a gap between both calculations might be concluded and, therefore, it may be that some energy savings estimates assigned to a particular measure in the EAP4+ include indirect savings calculated through top-down indicators.

Secondly, Table 1 incorporates the direct energy savings calculated through bottom-up indicators. However, as Table A. 2 shows, not all efficiency measures have been measured with bottom-up indicators. For example, those efficiency measures that were not assigned with potential savings are not assessed, but also, there are efficiency measures that have not been assessed due to the lack of available data for a bottom-up indicator.

Thirdly, the evaluation of the EAP4 +, as mentioned before, does not contain an estimate of the private investment made by sectors or measures. Therefore, an evaluation cannot be made on which measures generate more energy savings with lower total budget, both 
private and public, but only those which mean lower costs for the government, because only public investment data is available.

Fourthly, the EEAP (2011) also recognises that the overall energy savings achieved in some sectors could be affected by a double counting, but they have been reduced to a minimum.

\section{Conclusion and Policy Implications}

The final energy savings estimate in the EAP4 + for 2010 (10,273 ktoe) was higher than the achieved value of 2,642 ktoe, considering the bottom-up indicators, that is, only direct energy savings. In percentage terms, the final energy savings achieved were just $26 \%$ of the targeted amount.

Despite the important amount of public funds finally spent in the energy efficiency measures, implemented through the EAP4+ in $2010(242,631 \mathrm{k} €)$, the effectiveness indicator for the plan is 0.3 , that is, the energy savings achieved, were only a quarter of what was expected.

Among the reasons why this happened was the low effectiveness of the results achieved in the transport, building and equipment sectors. In fact, those sectors are considered the diffuse sectors and the priority of energy policy agendas which, in the case of Spain, have not been able to achieve the energy savings that were expected from them. The first conclusion is that the measures applied to these sectors should be reconsidered as stated in the European Commission (2014). In fact, these sectors have large potential energy 
savings and therefore consumers should be encouraged to purchase more efficient innovative goods (Gaspar and Antunes, 2014). This is why governments should provide financial instruments that allow all sectors of the economy to access the new technologies.

In the case of the transport sector, the low effectiveness is due to the fact that most of the energy efficiency measures have not been assessed, and therefore, the effectiveness indicator is not real. In the case of the building sector, the measures have not produced the desirable effects although they received $60 \%$ of the funds targeted. Finally, in the case of the equipment sector, the energy savings achieved, by the only measure assessed, were insignificant (56 ktoe) when considering that it received the highest amount of funds $(55,333 \mathrm{k} €)$. In these three sectors, the diminishing of energy savings was not proportional to the decreasing of the budget. However, this cannot be the reason why they show a lower effectiveness. The lack of information about energy savings achieved and budgets allocated have to be taken into consideration for the final analysis.

However, the overall energy savings achieved in 2010 cannot be limited to the bottomup calculations. Therefore, the EAP4+ must also be analysed considering the energy savings achieved, through top-down calculations, in order to complement the previous results. The final energy savings achieved through top-down indicators (4,720 ktoe) represented $4.8 \%$ of hypothetical final energy consumption in 2010. The EEAP calculates the percentage of achieved energy savings in 2010 over the energy consumption that would have arisen if the efficiency measures had not been implemented during 2007 and 2010. Therefore, the achieved energy savings are compared with the hypothetical energy consumption instead of the real energy consumption in 2010. 
The top-down indicators show that the transport and building sectors were responsible for the highest energy savings, when both direct and indirect energy savings are considered. In the first case, road transport achieved the most important energy savings and in the second case, is was because of thermal envelope and installation rehabilitation.

The combination of results that come from bottom-up and top-down indicators allow concluding remarks to be made about the transport and building sectors. As they are both diffuse sectors, the energy savings achieved, considering direct and indirect effects, are large. However, the direct energy savings are still limited, and there is scope for reduction. Future plans should improve the energy saving measures in these two sectors. In fact, in the EU, the biggest potential savings are considered to be in the building sector (Broin et al., 2013, Yearwood-Travezan et al., 2013 and Streimikiene, 2014), due to the number of cost-effective efficiency technologies and measures that could be deployed in the sector.

The sectoral analysis of policy measures serves as a basis for the design of future energy saving and efficiency measures. Specifically, compared with the EAP4 +, the sectoral measures proposed in the second Action Plan (EEAP, 2011), are characterised by continuity and, with the exception of the Industrial sector, its measures have been almost completely renewed.

However, it is important to note that the distribution of public funding among measures and sectors in the EEAP (2011) has undergone remarkable changes from those in the EAP4 +, with a significant increase in support for the transport and buildings sectors, consistent with the recommendations made by Mendiluce (2012) and from our results. In both sectors, the projected energy savings are larger, because, although they are 
responsible for almost $60 \%$ of final energy consumption in Spain, they are efficient sectors and therefore areas in which public investment can achieve significant energy saving yields.

The other sectors reduce their relative share of the total public funding available through the EEAP (2011), either because, as in the case of the Industrial sector, energy saving possibilities are more limited in the context of current economic and financial crises, or, as in the case of the public service and equipment sectors, because the implemented measures have achieved only limited efficacy and effectiveness per monetary unit. Finally, despite the efficacy and energy savings per monetary unit of measures in the agriculture and fisheries sector in 2010, these have been targeted for budget reductions in the EEAP (2011).

To sum up, the implementation of energy saving and efficiency measures entails the need to evaluate achievements in terms of energy saving and spending. Thus, it must be among the priorities of government agendas to account for energy savings that result from each of the energy efficiency measures implemented through their savings plans. Achieving this objective is very laborious, in the case of Spain, because the responsibility for implementation of these measures is decentralised to regional and local administrations. It is therefore necessary that central, regional and local administrations become involved, in order to get better estimates of the energy savings achieved, and thus affect the design of future energy efficiency measures at the lowest possible cost to the citizens. 


\section{Acknowledgements}

The authors wish to acknowledge the funding provided by the following institutions: the Andalusian Regional Government (project SEJ-132), the Roger Torné Foundation through the Energy and Environmental Economics Chair at the University of Seville, the Spanish Ministry of Economy and Competitiveness (ECO2014-56399-R Project) and FONDECYT of Chile's Ministry of Education (1150025 Project). Additionally, authors are also grateful for the reviewers' comments received at the Second Workshop on Economic Theory and Political Economy at the University of Seville, in September 2012.

\section{References.}

Al-Mansour, F. (2011) Energy Efficiency trends and policy in Slovenia, Energy, 36, pp. $1868-1877$.

Andrés, L., \& Padilla, E. (2015). Energy intensity in road freight transport of heavy goods vehicles in Spain. Energy Policy, 85, pp. 309-321.

ANFAC. (2014). Datos básicos del sector. http://www.anfac.com/estadisticas.action?accion=estad_datosSector. $\quad$ Last Access 8/12/2014.

Annunziata, E., Rizzi, F., \& Frey M. (2014). Enhancing energy efficiency in public buildings: The role of local energy audit programmes, Energy Policy, 69, pp. 364373.

AP (2005). Action Plan 2004-2007, approved by the Council of Ministers on 8 July, 2005. Aranda-Usón, A., Ferreira, G., Mainar-Toledo, M.D., \& Scarpellini, S. (2012) Energy consumption analysis of Spanish food and drink, textile, chemical and nonmetallic mineral products sectors, Energy, 42, pp. 477-485. 
Baležentis, A., Baležentis T. \& Streimikiene, D. (2011). The energy intensity in Lithuania during 1995-2009: A LMDI approach. Energy Policy, 39 (11).

Broin, E. O., Mata, E., Göransson, A., \& Johnsson, F. (2013). The effect of improved efficiency on energy savings in EU-27 buildings, Energy, 57, pp. 134-148.

Carvalho, M. (2012) EU energy and climate change strategy, Energy, 40, pp. 19-22.

Colinet, M.J., \& Román, R. (2016). LMDI decomposition analysis of energy consumption in Andalusia (Spain) during 2003-2012: the energy efficiency policy implications. Energy Efficiency, Volume 9, Issue 3, pp 807-823

Dineen, D., \& Gallachóir, B. Ó. (2011). Modelling the impacts of building regulations and a property bubble on residential space and water heating. Energy and Buildings, 43(1), pp. 166-178.

Directive 2006/32/EC of the European Parliament and of the Council of 5 April 2006, on energy end-use efficiency and energy services and repealing Council Directive 93/76/EEC. Official Journal of the EU, 27.4. 2006.

Directive 2009/28/EC of the European Parliament and of the Council of 23 April 2009 on the promotion of the use of energy from renewable sources, amending and subsequently repealing Directives 2001/77/EC and 2003/30/EC

Directive 2012/27/EU of the European Parliament and of the Council of 25 October 2012 on energy efficiency, amending Directives 2009/125/EC and 2010/30/EU and repealing Directives 2004/8/EC and 2006/32/EC.

E4. Spanish Energy Saving and Efficiency Strategy, 2004-2012 approved by the Spanish Council of Ministers on 28 November, 2003.

EAP 4+ (2007). Action Plan 2008-2012 for the Energy Saving and Efficiency Strategy approved by the Spanish Council of Ministers on 20 July, 2007. 
EEAP (2011). Second National Action Plan of Energy Saving and Efficiency, approved by the Spanish Council of Ministers on 29 July, 2011.

EECCEL (2007). Spanish Climate Change and Clean Energy Strategy approved by the Spanish Council of Ministers on 2 November, 2007.

European Commission (2006). Action Plan for Energy Efficiency: Realising the Potential. COM(2006) 545.

European Commission (2009). Synthesis of the complete assessment of all 27 national Energy Efficiency Action plans as required by Directive 2006/32/EC on energy end-use efficiency and energy services. Brussels 23 June 2009.

European Commission (2011a). Communication "Energy Efficiency Plan 2011”. Impact assessment.

European Commission (2011b). Communication from the Commission to the European Parliament, the Council, the European Economic and Social Committee and the Committee of the Regions Commission staff working document. Energy Efficiency Plan 2011. COM(2011) 109.

European Commission (2014). Communication from the Commission to the European Parliament, the Council, the European Economic and Social Committee and the Committee of the Regions . A policy framework for climate and energy in the period from 2020 to 2030. $\mathrm{COM}(2014) 15$ final.

European Council (2010). European Strategy 20 approved by the European Council on June 17, 2010.

Evaluation and Quality Agency (2014). Evaluación del Plan de Ahorro y Eficiencia Energética 2008-2012. Ministerio de Hacienda y Administracions Públicas. 
Fernández González, P., Landajo, M., \& Presno, M.J. (2013) The Divisia real energy intensity indices: Evolution and attribution of percent changes in 20 European countries from 1995 to 2010. Energy 58, pp. 340-349.

Fernández-Membrive, V. J., Lastra-Bravo, X. B., \& Tolón-Becerra, A. (2015). Costbenefit analysis of changes in energy in building technology in Southeast Spain. Energy and Buildings, 103, pp. 29-37.

Filippini, M., Hunt, L.C., \& Zorit, J. (2014). Impact of energy policy instruments on the estimated level of underlying energy efficiency in the EU residential sector. Energy Policy, 69, pp. 73-81.

Galarraga, I., Abadie, L.M., \& Ansuategi, A. (2013). Efficiency, effectiveness and implementation feasibility of energy efficiency rebates: The "Renove" plan in Spain. Energy Economics, 40(1), pp. 98-107.

Galarraga, I., Abadie, L. M., \& Kallbekken, S. (2016). Designing incentive schemes for promoting energy-efficient appliances: A new methodology and a case study for Spain. Energy Policy, 90, pp. 24-36.

Gaspar, R., \& Antunes, D. (2014). Energy Efficiency and Appliance's Characteristics Considered Prior to Purchase: Differences and Similarities between Ireland, Germany, Portugal, Greece, Poland, Spain and Italy. International Journal of Green Energy, 13(6), pp. 546-555.

Haydt, G., Leal, V., \& Dias, L. (2013). Uncovering the multiple objectives behind national energy efficiency planning, Energy policy, 54, pp. 203-209.

Hull, D., Gallachoir, B., \& Walker, N. (2009). Development of a modelling framework in response to new European energy-efficiency regulatory obligations: The Irish experience. Energy Policy, 37, pp. 5363-5375. 
International Energy Agency (2013). World Energy Outlook Special Report. Redrawing the Energy-Climate Map. OECD.

Keeney, R.L. (1996). Value-focused thinking: Identifying decision opportunities and creating alternatives. European Journal of Operational Research, 92, pp. 537549.

Linares, P., \& Labandeira, X. (2010). Energy efficiency: economics and policy, Journal of Economic Surveys, 24(3), pp. 573-592.

Mendiluce, M. (2012). Los determinantes del consumo energético en España: ¿Se ha mejorado la eficiencia energética? Papeles de Economía Española, 134, pp. 196210. ISSN: 0210-9107.

Mendiluce, M., Perez-Arriaga, I., \& Ocaña, C. (2010). Comparison of the evolution of energy intensity in Spain and in the EU15. Why is Spain different? Energy Policy, 38, pp. 639-645.

Mendiluce, M., \& Schipper, L. (2011). Trends in passenger transport and freight energy use in Spain. Energy Policy, 39, pp. 6466-6475.

Ministry of Industry, Energy and Tourism (2014). 2014-2020 National Energy Efficiency Action Plan. Spain.

NAP (2006). National Allocation Plan allowances of greenhouse gases 2008-2012. Approved by the Spanish Council of Ministers on 8 July, 2006.

Odyssee (2012). Energy Efficiency Indicators in Europe. Country Profiles. Spain; 2012 REP (2005). Renewable Energy Plan 2005-2010, approved by the Spanish Council of Ministers Agreement of 26 August, 2005.

Royal Decree 314/2006, dated 17 March, which approves the Technical Building Code.

Official State Bulletin: 78, dated 28 March, Spain, 2006. 
Royal Decree 47/2007, dated 19 January, which approves the Basic Procedure for the Energy Efficiency Certification of Newly-Constructed Buildings, Spain, 2007.

Royal Decree 1027/2007, dated 20 July, which approves the Regulation of Thermal Installations in Buildings. Official State Bulletin: 27, dated 31 January, Spain, 2007.

Sobrino, N., \& Monzon, A. (2014). The impact of the economic crisis and policy actions on GHG emissions from road transport in Spain. Energy Policy, 74, pp. 486-498.

Streimikiene, D., Volochovic, A., \& Simanaviciene, Z. (2012). Comparative assessment of policies targeting energy use efficiency in Lithuania. Renewable and Sustainable Energy Reviews, 16, pp. 3613-3620.

Streimikiene, D. (2014). Residential energy consumption trends, main drivers and policies in Lithuania. Renewable and Sustainable Energy Reviews, 35, pp. 285293.

Tolón-Becerra, A., Lastra-Bravo,X.B., Fernández-Membrive, V.J., \& Flores-Parra, I. (2013). Opportunities in Spanish energy efficiency. Current situation, trends and potential in the building sector. Energy Procedia, 42, pp. 63-72.

Yearwood-Travezan, J., Harmsen, R., \& Toledo, G. (2013). Policy analysis for energy efficiency in the built environment in Spain. Energy Policy, 61, pp. 317-326.

Zabalza, I., Valero, A., \& Aranda, A. (2011). Life cycle assessment of building materials: Comparative analysis of energy and environmental impacts and evaluation of the eco-efficiency improvement potential. Building and Environment, 46, pp. 11331140. 
Table 1: Effectiveness and efficiency of final energy saving measures implemented by EAP4 + in Spain in 2010

\begin{tabular}{|c|c|c|c|c|c|c|c|c|c|c|}
\hline \multirow{2}{*}{\multicolumn{2}{|c|}{ MEASURES PROPOSED IN THE 2008-2012 ACTION PLAN }} & \multirow{3}{*}{$\begin{array}{r}\text { (1) } \\
\begin{array}{r}\text { Energy eff. } \\
\text { Measure }^{\mathrm{K}}\end{array} \\
\mathrm{I}\end{array}$} & \multirow{4}{*}{$\begin{array}{c}\text { (2) } \\
\text { Bottom-up } \\
\text { Indicator }^{\mathrm{L}} \\
\mathrm{BU} \mathrm{pm}\end{array}$} & \multicolumn{2}{|c|}{$\begin{array}{c}(3) \\
\text { FINAL ENERGY } \\
\text { SAVINGS (ktoe) }\end{array}$} & \multirow{4}{*}{$\begin{array}{r}\begin{array}{c}\text { (4) } \\
\text { Effectiv. } \\
\text { b/a }\end{array} \\
\\
\\
0.4 \\
\end{array}$} & \multicolumn{2}{|c|}{$\begin{array}{c}(5) \\
\text { Public funding } \\
(€ \times 1000)\end{array}$} & \multirow{2}{*}{$\begin{array}{c}(6) \\
\text { Energy } \\
\text { savings per } \\
\text { monetary } \\
\text { unit achieved } \\
\text { (toe/€x1000) } \\
\text { b/d } \\
\end{array}$} & \multirow{2}{*}{$\begin{array}{c}(7) \\
\text { Energy } \\
\text { savings per } \\
\text { monetary } \\
\text { unit targeted } \\
\text { (toe/€x1000) } \\
\text { a/c }\end{array}$} \\
\hline & & & & $\begin{array}{c}\text { (a) } \\
\text { Target }\end{array}$ & $\begin{array}{c}\text { (b) } \\
\text { Achieved } \\
M\end{array}$ & & $\begin{array}{l}\text { (c) } \\
\text { Target }\end{array}$ & $\begin{array}{c}(d) \\
\text { Achieved }\end{array}$ & & \\
\hline 1 & Sustainable Urban Mobility Plans & & & 959 & 563 & & 48,385 & 8,962 & 62.8 & 19.8 \\
\hline 2 & Mobility plans for companies and activity centres & I & & 320 & & & 7,291 & & & 43.9 \\
\hline 3 & Greater Participation of Collective Means in Road Transport & I & $\mathrm{BU} \mathrm{cc}$ & 192 & -12 & -0.1 & 5,292 & 367 & -32.7 & 36.3 \\
\hline 4 & Greater Participation of Railways in Inter-urban Transport & I & $\mathrm{BU}_{\text {fipas }}+\mathrm{BU}_{\text {fimer }}$ & 767 & 64 & 0.1 & 2,185 & N/A & N/A & 351 \\
\hline 5 & Greater Participation of Maritime Transport in freight movements & I & P13 & 128 & -1 & -0.01 & 2,959 & N/A & N/A & 43.3 \\
\hline 6 & Transport Infrastructure Management & I & N/A & 1,598 & N/A & N/A & 1,427 & N/A & N/A & $1,119.8$ \\
\hline 7 & Road Transport Fleet Management & I & BU gf & 320 & 1 & 0.0 & 4,110 & 2,355 & 0.4 & 778.6 \\
\hline 8 & Aircraft Fleet Management & I & N/A & 64 & $\mathrm{~N} / \mathrm{A}$ & N/A & 286 & N/A & N/A & 223.8 \\
\hline 9 & Eco-driving for cars and vans & $\mathrm{T}$ & BU cet & 383 & 41 & 0.1 & 1,728 & 3,324 & 12.3 & 221.6 \\
\hline 10 & Road Transport fleet eco-driving & $\mathrm{T}$ & BU cec & 383 & 52 & 0.1 & 1,123 & 2,919 & 17.8 & 341.1 \\
\hline 11 & Efficient Piloting in Aviation Sector & $\mathrm{T}$ & N/A & 64 & N/A & $\mathrm{N} / \mathrm{A}$ & 1,064 & N/A & N/A & 60.1 \\
\hline 12 & Renewal of Road Transport Fleets & I & BU rt & 320 & 1 & 0.0 & 1,206 & 1,605 & 0.6 & 265.3 \\
\hline 13 & Renewal of Aircraft Fleet & I & N/A & 64 & N/A & N/A & 291 & N/A & N/A & 219.9 \\
\hline 14 & Renewal of Maritime Fleet & I & N/A & 64 & $\mathrm{~N} / \mathrm{A}$ & N/A & 542 & N/A & N/A & 118.1 \\
\hline 15 & Renewal of Private Cars & $\mathrm{I}$ & $\Sigma \mathrm{BU}_{\mathrm{rpi}}$ & 767 & 221 & 0.3 & 6,559 & 4,809 & 46 & 116.9 \\
\hline $\mathbf{A}$ & TOTAL TRANSPORT SECTOR & & & 6,393 & 930 & 0.2 & 84,448 & 24,341 & 38.2 & 53.7 \\
\hline 16 & Cooperation Agreements & $\mathrm{P}$ & N/A & 0 & N/A & N/A & 0 & N/A & N/A & 0.0 \\
\hline 17 & Energy Audits & I & N/A & 0 & $\mathrm{~N} / \mathrm{A}$ & N/A & 570 & 1,981 & N/A & 0.0 \\
\hline 18 & Grants for Strategic Projects & $\mathrm{I}$ & $\mathrm{BU}$ indC & 1,561 & 804 & 0.5 & 73,918 & 25,149 & 32 & 21.1 \\
\hline B & TOTAL INDUSTRY SECTOR & & & 1,561 & 804 & 0.5 & $\mathbf{7 4 , 4 8 8}$ & 27,130 & 29.6 & 21 \\
\hline 20 & Rehabilitation of the thermal envelope of existing buildings & I & BU et & 290 & 18 & 0.0 & 35,030 & 36,577 & 0.5 & 82.8 \\
\hline 21 & $\begin{array}{l}\text { Improvement of the energy efficiency of thermal installations of existing } \\
\text { buildings }\end{array}$ & $\mathrm{I}$ & BU it & 337 & 50 & 0.1 & 48,663 & 38,803 & 1.3 & 6.9 \\
\hline 22 & $\begin{array}{l}\text { Improvement of the energy efficiency of internal lighting plants of existing } \\
\text { buildings }\end{array}$ & I & $\mathrm{BU}_{\mathrm{i} 1}+\mathrm{Bu}_{\mathrm{i} 2}+\mathrm{BU}_{\mathrm{i} 3}$ & 668 & 301 & 0.4 & 35,258 & 21,093 & 14.3 & 18.9 \\
\hline 23 & $\begin{array}{l}\text { Promotion of construction of new buildings and rehabilitation of existing } \\
\text { buildings with high energy rating }\end{array}$ & I & $\mathrm{BU}_{\mathrm{pe}}+\mathrm{BU}_{\mathrm{cte}}$ & 263 & 228 & 0.9 & 41,783 & 2,028 & 112.4 & 6.3 \\
\hline 24 & Revision of energy requirements in building regulations & I & N/A & 0 & N/A & N/A & 0 & N/A & N/A & 0.0 \\
\hline $\mathbf{C}$ & TOTAL BUILDING SECTOR & & & 1,558 & 579 & 0.4 & 160,734 & 98,501 & 5.9 & 9.7 \\
\hline
\end{tabular}




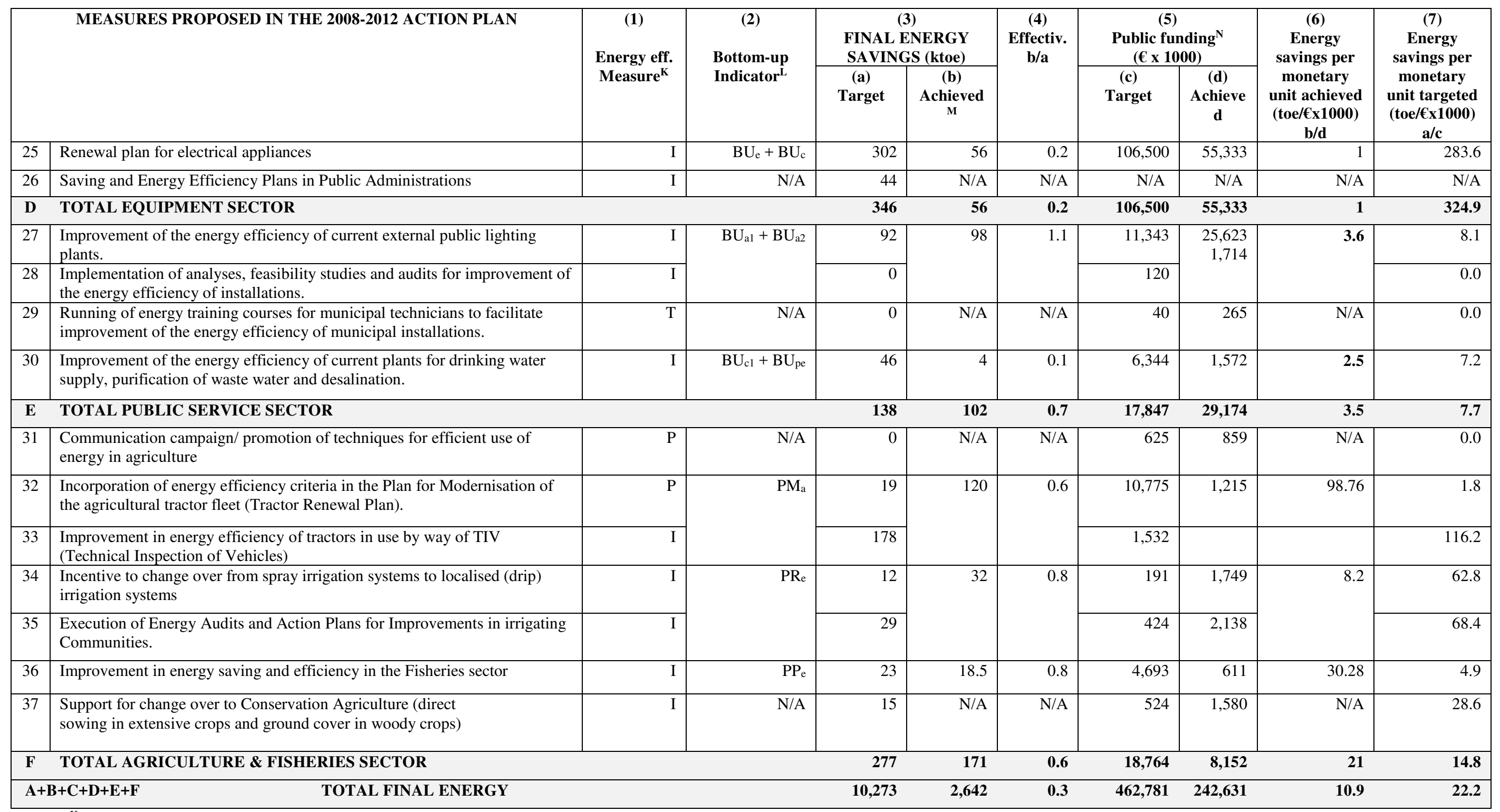

$\mathrm{K}$ This column identifies the type of energy efficiency measure applied, that is, an investment measure (I), a promotion measure (P) or a training measure (T).

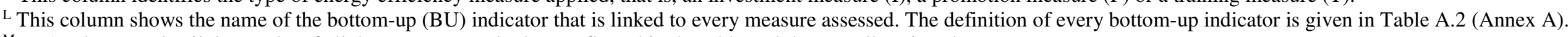

${ }^{\mathrm{M}}$ EEAP does not detail the results of all the measures, only those reflected in the table and the overall savings by sector.

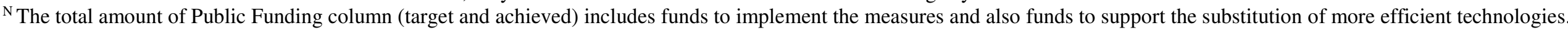

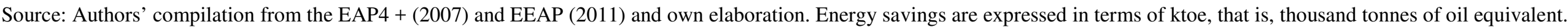


Table A.1. Breakdown of top-down indicators by sectors.

\begin{tabular}{|c|c|c|c|c|c|c|}
\hline \multicolumn{4}{|l|}{ Sector } & \multicolumn{2}{|c|}{ Energy indicator } & Unit \\
\hline \multirow[t]{2}{*}{ Industry } & \multirow{2}{*}{\multicolumn{3}{|c|}{ Parametric method Divisia }} & $\begin{array}{l}\text { L } \\
\text { technolo } \\
\text { gical }\end{array}$ & $\begin{array}{l}\text { Indicator of technological effect } \\
\text { of industrial sub-sector }\end{array}$ & ktoe $/ 10^{6} €$ \\
\hline & & & & L & $\begin{array}{l}\text { Indicator of structural effect of } \\
\text { industrial sub-sector }\end{array}$ & ktoe $/ 10^{6} €$ \\
\hline \multirow[t]{9}{*}{ Transport } & \multirow[t]{3}{*}{ Road } & \multirow{2}{*}{\multicolumn{2}{|c|}{ Passengers }} & $\begin{array}{l}\mathrm{BU}_{\mathrm{rp}}+ \\
\mathrm{BU}_{\text {cet }}\end{array}$ & $\begin{array}{l}\text { Unitary savings per vehicle } \\
\text { replaced by type of replacement + } \\
\text { unitary savings associated to Eco- } \\
\text { driving courses }\end{array}$ & toe/pkm \\
\hline & & & & $\begin{array}{l}\text { M53/ } \\
\text { PB }\end{array}$ & $\begin{array}{l}\text { Energy consumption per buses } \\
\text { fleet }\end{array}$ & toe/veq \\
\hline & & \multicolumn{2}{|c|}{ Freight } & $\begin{array}{l}\text { M52/ } \\
\text { A2 }\end{array}$ & $\begin{array}{l}\text { Energy consumption of trucks and } \\
\text { light vehicles per vehicle fleet } \\
\text { equivalent }\end{array}$ & toe/veq \\
\hline & \multirow[t]{2}{*}{ Railway } & \multicolumn{2}{|c|}{ Passengers } & P10 & $\begin{array}{llr}\text { Energy consumption } & \text { of } \\
\text { passengers rail transport per } \\
\text { passenger traffic }\end{array}$ & toe/pkm \\
\hline & & \multicolumn{2}{|c|}{ Freight } & P11 & $\begin{array}{l}\text { Energy consumption of freight rail } \\
\text { transport per freight traffic }\end{array}$ & toe/pkm \\
\hline & \multicolumn{3}{|c|}{ Maritime (freight) } & M7 & $\begin{array}{l}\text { Energy consumption of freight sea } \\
\text { transport per freight traffic }\end{array}$ & toe/pkm \\
\hline & \multicolumn{3}{|c|}{ Air (domestic passengers) } & Mav & $\begin{array}{l}\text { Energy consumption } \text { of } \\
\text { passengers air transport in } \\
\text { domestic flights per operations } \\
\text { (number of flights) }\end{array}$ & toe/pkm \\
\hline & \multirow[t]{2}{*}{$\begin{array}{l}\text { Modal } \\
\text { shift }\end{array}$} & \multicolumn{2}{|c|}{$\begin{array}{l}\text { Passengers car to } \\
\text { collective }\end{array}$} & P12 & $\begin{array}{l}\text { Transfer of passenger vehicle } \\
\text { traffic to collective modes (bus, } \\
\text { train and underground) }\end{array}$ & $\%$ \\
\hline & & \multicolumn{2}{|c|}{$\begin{array}{l}\text { Freight road to } \\
\text { railway/maritime }\end{array}$} & P13 & $\begin{array}{l}\text { Transfer of freight road traffic to } \\
\text { rail and maritime modes }\end{array}$ & $\%$ \\
\hline \multirow[t]{5}{*}{ Building } & \multirow{4}{*}{\multicolumn{2}{|c|}{ Residential }} & \multirow[t]{3}{*}{$\begin{array}{l}\text { Envelope and } \\
\text { thermal } \\
\text { equipment }\end{array}$} & $\mathrm{P} 1$ & $\begin{array}{l}\text { Energy consumption of } \\
\text { households for space heating per } \\
\text { floor area (adjusted for climatic } \\
\text { conditions) }\end{array}$ & toe $/ \mathrm{m}^{2}$ \\
\hline & & & & $\mathrm{P} 2$ & $\begin{array}{l}\text { Energy consumption of } \\
\text { households for space cooling per } \\
\text { floor area (adjusted for climatic } \\
\text { conditions) }\end{array}$ & toe $/ \mathrm{m}^{2}$ \\
\hline & & & & P3 & $\begin{array}{l}\text { Energy consumption } \\
\text { households for lighting per } \\
\text { dwelling }\end{array}$ & toe/inhabitant \\
\hline & & & Lighting & P5 & $\begin{array}{llr}\begin{array}{l}\text { Electricity consumption } \\
\text { households for lighting per } \\
\text { dwelling }\end{array} & \\
\end{array}$ & toe/home \\
\hline & Service & & $\begin{array}{l}\text { Envelope and } \\
\text { thermal }\end{array}$ & $\mathrm{M} 311$ & $\begin{array}{l}\text { Non-electric energy consumption } \\
\text { in service sector for space heating } \\
\text { per employee in full time } \\
\text { equivalent (adjusted for climatic }\end{array}$ & toe/employee \\
\hline
\end{tabular}




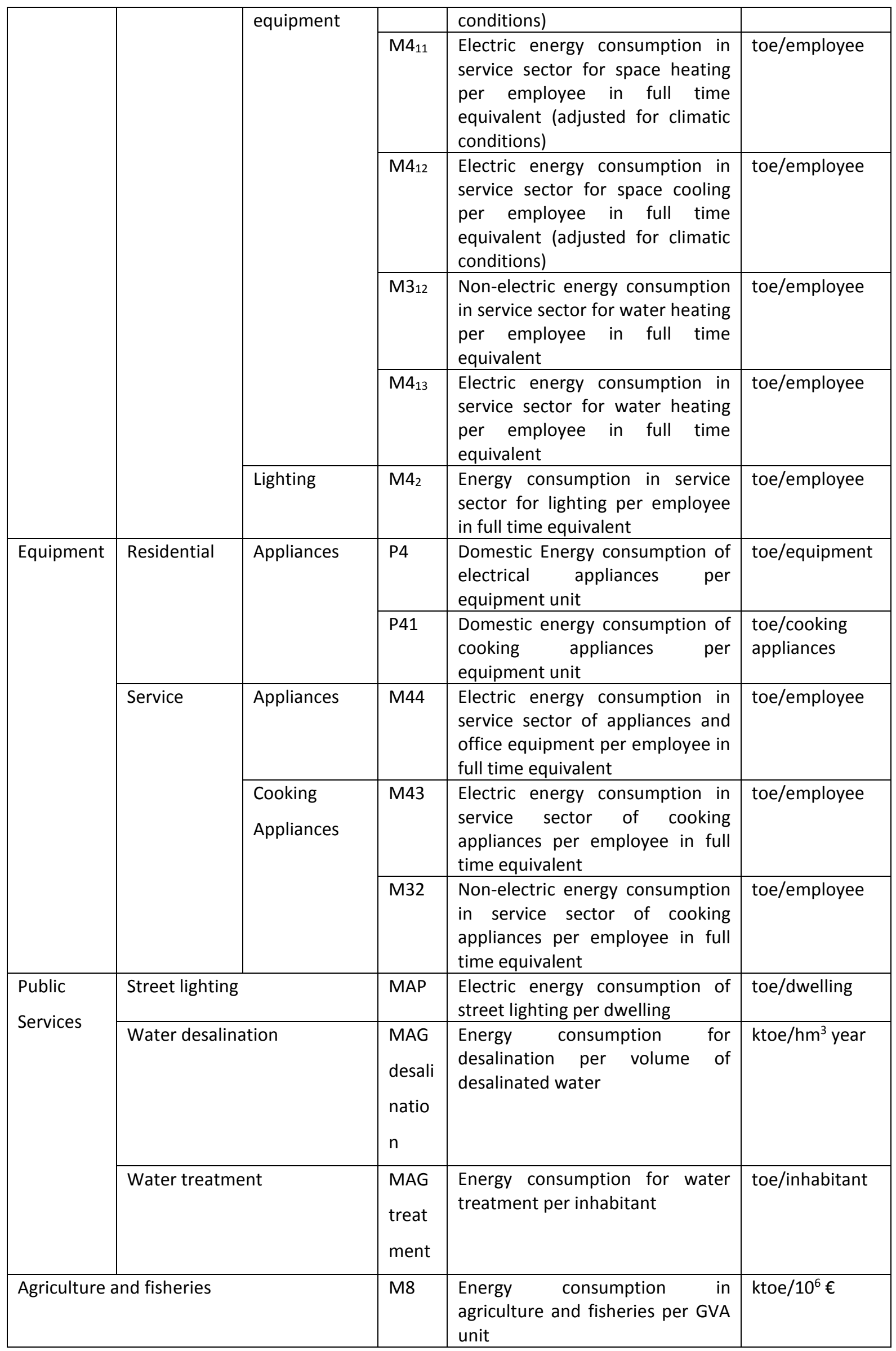


Source: Authors' compilation from the EAP4 + (2007) and EEAP (2011) 
Table A.2 Breakdown of bottom-up (BU) indicators for estimating direct energy savings by mechanisms and measures.

\begin{tabular}{|c|c|}
\hline $\mathrm{BU} \mathrm{pm}$ & $\begin{array}{l}\text { Sustainable Urban Mobility Plans (PMUS) and Mobility plans for companies and } \\
\text { activity centres }\end{array}$ \\
\hline $\mathrm{BU} \mathrm{cc}_{\mathrm{c}}$ & Greater participation of collective means of road transport \\
\hline$B U_{\text {fipas }}$ & Greater share of passenger rail transport in Freight Transport \\
\hline$B U_{\text {fimer }}$ & Greater share of rail in Freight Transport \\
\hline$B U_{g f}$ & Road transport fleet management \\
\hline $\mathrm{BU}$ cet & Eco-driving for cars and vans \\
\hline $\mathrm{BU}$ cec & Eco-driving for trucks and buses \\
\hline $\mathrm{BU}_{\mathrm{rt}}$ & Renovation of road transport fleets \\
\hline$\Sigma \mathrm{BU}_{\mathrm{rpi}}$ & Replacing car fleet \\
\hline $\mathrm{BU}$ rp1 & Natural replacing car fleet \\
\hline $\mathrm{BU}$ rp2 & Plan PREVER \\
\hline $\mathrm{BU}$ rp3 & Plan VIVE \\
\hline $\mathrm{BU} \mathrm{rp} 4$ & Plan 2000E \\
\hline $\mathrm{BU}$ rp5 & Strategy to Promote Electric Vehicle in Spain 2010-2013 \\
\hline $\mathrm{BU}$ rp6 & IDEA - Regional administrations cooperation programme + IDEA strategic projects \\
\hline \multicolumn{2}{|c|}{ Transport Sector } \\
\hline $\mathrm{BU}$ indC & C. agreements IDEA - regional administration \\
\hline $\mathrm{BU}$ indC & Strategic Projects \\
\hline \multicolumn{2}{|c|}{ Industry Sector } \\
\hline$B U_{\text {et }}$ & Renove scheme of thermal envelope of buildings \\
\hline$B U_{\text {it }}$ & Renove scheme of thermal installation \\
\hline $\mathrm{BU}$ pe & IDEA support programmes to strategic projects \\
\hline $\mathrm{BU}$ cte & Technical Code for Building \\
\hline $\mathrm{BU}_{\mathrm{i} 1}$ & Programme of distribution low-consumption light bulbs \\
\hline $\mathrm{BU}_{\mathrm{i} 2}$ & Programme of low-consumption light bulbs " 2 for 1 " \\
\hline $\mathrm{BU}_{\mathrm{i} 3}$ & Improved interior lighting installations of existing buildings \\
\hline
\end{tabular}




\begin{tabular}{|c|c|}
\hline $\mathrm{BU}_{\mathrm{e}}$ & White-line appliances \\
\hline $\mathrm{BU}_{\mathrm{c}}$ & Cooking appliances and ovens \\
\hline \multicolumn{2}{|c|}{ Equipment sector } \\
\hline $\mathrm{BU}$ a1 & Renewal of existing public street lighting installations \\
\hline $\mathrm{BU} \mathrm{U}_{2}$ & Programme to replace existing traffic lights with LED \\
\hline $\mathrm{BU} \mathrm{c1}$ & $\begin{array}{l}\text { Improvements in installations for treatment and supply of drinking water and the } \\
\text { desalinisation and desludging of water }\end{array}$ \\
\hline$B U_{p e}$ & Strategic projects \\
\hline \multicolumn{2}{|c|}{ Public Services sector } \\
\hline $\mathrm{PM}_{\mathrm{a}}$ & Energy consumption in machinery per exploitation \\
\hline $\mathrm{PR}_{\mathrm{e}}$ & Energy consumption related to irrigation per hectare \\
\hline $\mathrm{PP}_{\mathrm{e}}$ & Energy consumption related to fisheries per vessel \\
\hline
\end{tabular}

Source; Authors' compilation from the EEAP (2011). 
Table A.3. Energy savings achieved by sectors in 2010 (base year 2007)

\begin{tabular}{|c|c|c|}
\hline Sector & $\begin{array}{l}\text { Top-down } \\
\text { Indicators }\end{array}$ & $\begin{array}{l}\text { Energy savings in } \\
2010 \text { (base year } \\
\text { 2007) (ktoe) }\end{array}$ \\
\hline \multicolumn{2}{|c|}{$\mathrm{P} 8+\mathrm{A} 2+\mathrm{PB}+\mathrm{P} 10+\mathrm{P} 11+\mathrm{M} 7+\mathrm{Mav}+\mathrm{P} 12+\mathrm{P} 13$} & 4,561 \\
\hline Road mode & $\mathrm{P} 8+\mathrm{A} 2+\mathrm{PB}$ & 4,910 \\
\hline Road Transport cars & P8 & 1006 \\
\hline Road transport freight & A2 & 3865 \\
\hline Road transport collective & $\mathrm{PB}$ & 40 \\
\hline Railway mode & $\mathrm{P} 10+\mathrm{P} 11$ & -207 \\
\hline Maritime mode & M7 & -100 \\
\hline Air mode & Mav & -48 \\
\hline Intermodal & $\mathrm{P} 12+\mathrm{P} 13$ & 6 \\
\hline B) Industrial sector & $\mathrm{LT}+\mathrm{LE}$ & $-2,866$ \\
\hline Technological effect & $\mathrm{LT}$ & $-3,988$ \\
\hline \multicolumn{2}{|l|}{ Wood, cork and furniture } & -317 \\
\hline \multicolumn{2}{|l|}{ Food, beverages and tobacco } & 215 \\
\hline \multicolumn{2}{|l|}{ Textiles, leather and footwear } & -41 \\
\hline \multicolumn{2}{|l|}{ Pulp, paper and printing } & -378 \\
\hline \multicolumn{2}{|l|}{ Chemicals } & 1,211 \\
\hline \multicolumn{2}{|l|}{ Non-metallic Minerals } & $-1,632$ \\
\hline \multicolumn{2}{|l|}{ Metallurgy and metal products } & -824 \\
\hline \multicolumn{2}{|l|}{ Machinery and mechanical equipment } & -1 \\
\hline \multicolumn{2}{|l|}{ Transport equipment } & -326 \\
\hline \multicolumn{2}{|l|}{ Electrical, electronic and optical equipment } & -53 \\
\hline \multicolumn{2}{|l|}{ Rest of the manufacturing industry } & $-1,843$ \\
\hline Structural effect & LE & 1,122 \\
\hline \multicolumn{2}{|l|}{ Wood, cork and furniture } & 196 \\
\hline \multicolumn{2}{|l|}{ Food, beverages and tobacco } & -409 \\
\hline \multicolumn{2}{|l|}{ Textiles, leather and footwear } & 82 \\
\hline \multicolumn{2}{|l|}{ Pulp, paper and printing } & -51 \\
\hline \multicolumn{2}{|l|}{ Chemicals } & $-1,253$ \\
\hline \multicolumn{2}{|l|}{ Non-metallic Minerals } & 1,957 \\
\hline \multicolumn{2}{|l|}{ Metallurgy and metal products } & 542 \\
\hline \multicolumn{2}{|l|}{ Machinery and mechanical equipment } & -21 \\
\hline \multicolumn{2}{|l|}{ Transport equipment } & 130 \\
\hline \multicolumn{2}{|l|}{ Electrical, electronic and optical equipment } & 12 \\
\hline \multicolumn{2}{|l|}{ Rest of the manufacturing industry } & -63 \\
\hline Sector & $\begin{array}{l}\text { Top-down } \\
\text { Indicators }\end{array}$ & $\begin{array}{l}\text { Energy savings in } \\
2010 \text { (base year }\end{array}$ \\
\hline
\end{tabular}




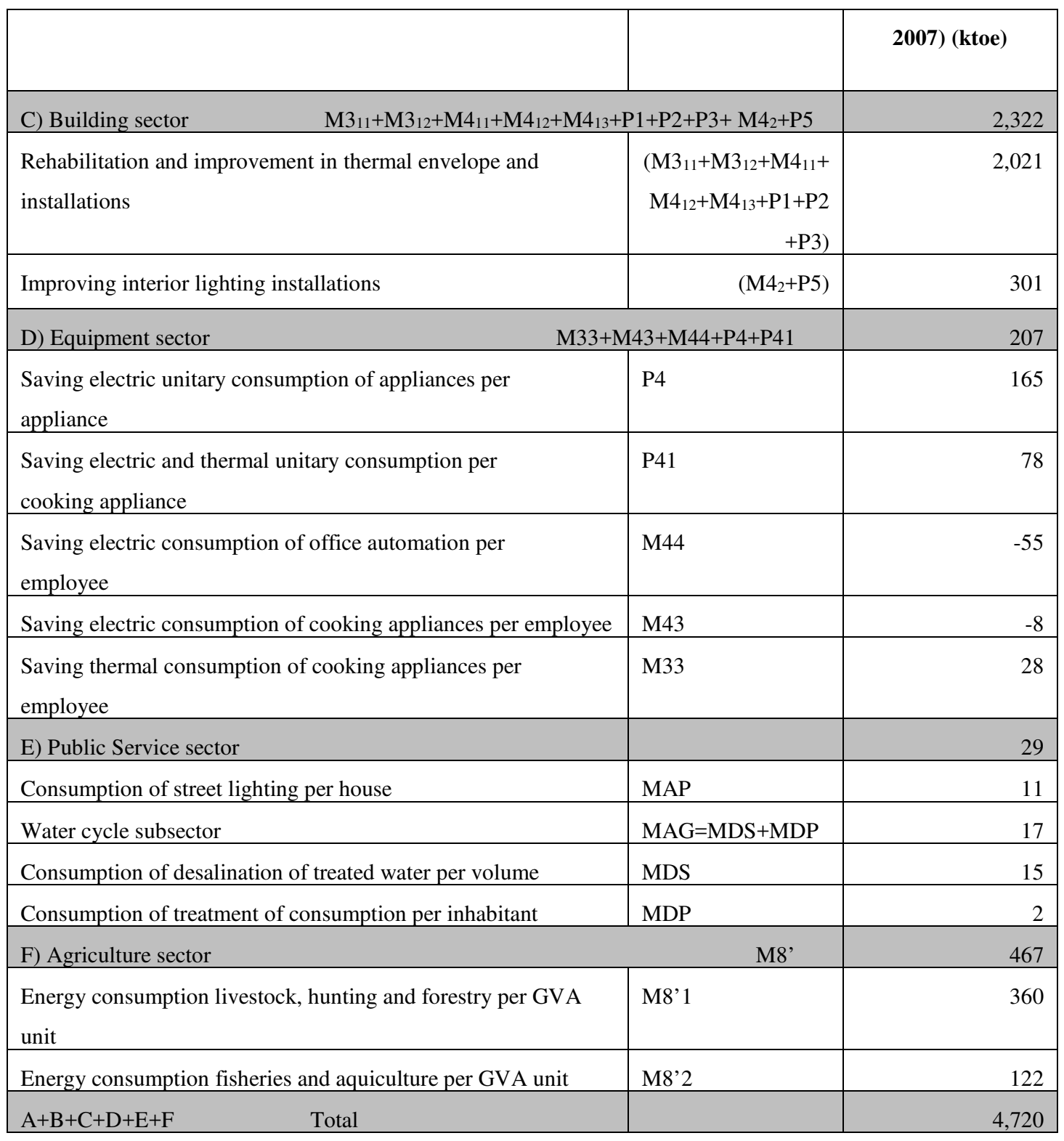

Source: Authors' compilation from the EEAP (2011) 